\title{
India as the Heritage of Medicinal Plant and their Use
}

\author{
Gangola S*, Khati P, Bhatt P, Parul and Anita Sharma \\ Department of Microbiology, College of Basic Science and Humanities, India
}

Submission: March 02, 2017; Published: May 30, 2017

"Corresponding author: Gangola S, Department of Microbiology, College of Basic Science and Humanities, GBPUA \& T Pant agar, US Nagar, Uttarakhand, India, Email: saindsaurabh@gmail.com

\begin{abstract}
Medicinal plants are useful for curing human diseases and play an important role in healing due to presence of phyto chemical constituents. india having a rich diversity of medicinal plants and rich plant diversity has provided an initial advantage to the local people for scrutinizing various plant species for the purpose of food, medicine, perfumes and spices. The natural and unique medicinal plants are used for curing various diseases/ailments and income generation. Ayurveda and other Indian literature have mentioned the use of plants in treatment of various human ailments. Medicinal plants are important source to combat the serious diseases in all over the world. The presence of different phytochemical constituents in plant parts confirms their potential as medicinal plants .
\end{abstract}

Keywords: Medicinal Plants; Phytochemical

\section{Introduction}

From thousands of year plant has been utilised as medicine. These medicines initially took the form of crude drugs such as tinctures, teas, poultices, powders, and other herbal formulations [1]. The Indian states which are leading producer of herbal plants having the highest medicinal value are Gujarat, Rajasthan, Haryana, Tamil Nadu, Andhra and Uttarakhand. After India, China is the largest producer of medicinal plants which having more than $40 \%$ of the global diversity (Financial express 2008).

Medicinal plant research has increased all over the world and collected the immense potential of medicinal plants used in various traditional systems [2]. Indian herbs are known all over Table 1: medicinal plants and their parts used. the world for the medicinal properties. About $90 \%$ of the herbs and medicinal plants in India are collected from the forest. India forests are the source of invaluable medicinal plants and became aware of the preventive and therapeutic properties of plants and being used for human health care.

These medicinal compounds are naturally gifted from the plant. The extraction and characterization of bioactive compounds from medicinal plants have resulted in the introduction of new drugs with high medicinal value. Treatment with natural origin bioactive medicine is gaining momentum towards increasing concern about virtually harmful synthetic medicine (Table 1) [3].

\begin{tabular}{|c|c|c|c|}
\hline Local name & Botanical name & Part used & Used to cure \\
\hline Kalonji & Nigella sativa & Seeds & Diarrhoea, dysentery \\
\hline Neem & Azadirachta indica & Root, bark, flower & Arthritis, bronchitis, cough, diabetes \\
\hline Dhatura & Dhatura stramonium & Leaves and fruits & Asthma, cardiac pains \\
\hline Tulsi & Ocimum sanctum & Leaves & Syphilis, bronchitis, stomachic \\
\hline Anar & Punica granatum & Seeds, flowers & Genito-urinary ailments, diarrhea \\
\hline Khajoor & Phoenix dactylifera & Fruit & Constipation, diabetes \\
\hline Methi & Trigonella foenum & Seeds & Antipyretic, leprosy \\
\hline Paiya & Prunus cerasoides & Bark, fruit & Antiseptic, antispasmodic \\
\hline Ajwain & Thymus vulgaris & Seeds & Bark, leaves, fruit, \\
seeds, latex & Skin diseases, neuralgia, constipation and gynecological diseases \\
\hline Peepal & Ficus religiosa & & \\
\hline
\end{tabular}




\section{Conclusion}

Presently many countries face large increases in the number of people suffering from diseases like diabetes, diarrhea, cancer, rheumatism, inflammation, jaundice, hepatic obstruction, pain, cold, cough, etc. remedies from medicinal plants are used with success to treat the disease. In India, Uttarakhand has diversity of aromatic and medicinal plants. These plants may be used as a huge amount of raw material for pharmaceutical industries for manufacturing the medicines. Uses of medicinal plants are time-tested and used by people worldwide and no side effects and cost effective compare to other system of medicine. With the changing scenario, there is a need to enhance and promote the conservation and cultivation of natural resources for medicinal plants. In addition to the requirement for conservation of medicinal plants it has also become essential to protect and patent the traditional knowledge.

\section{References}

1. Archana, Jatav S, Paul R, Tiwari A (2011) Indian Medicinal Plants: A rich source of natural immune-modulator. Int J Pharmacol 7(2): 198205.

2. Reische DL (1998) Antioxidant in food lipids. Chemistry, Nutrition and Biotechnology, New York: Marcel Dekker, Food Chemistry p. 423-448 1:1-80.

3. Samuelsson G (2004) Drugs of Natural Origin: a Textbook of Pharmacognosy, 5th Swedish Pharmaceutical Press, Stockholm. Swedish Pharmaceutical Press, Stockholm. J Nat Prod 68(4): 631.

\section{Your next submission with Juniper Publishers will reach you the below assets}

- Quality Editorial service

- Swift Peer Review

- Reprints availability

- E-prints Service

- Manuscript Podcast for convenient understanding

- Global attainment for your research

- Manuscript accessibility in different formats

( Pdf, E-pub, Full Text, Audio)

- Unceasing customer service

Track the below URL for one-step submission https://juniperpublishers.com/online-submission.php 